\title{
A Benevolent Astronomer: Further notes on L. J. Comrie
}

\author{
Lindsay Rollo
}

Britain, and particularly London, was neither a pleasant nor a safe place to be in 1940. Nor were the prospects of the city all that welcoming.

In May Winston Churchill became Prime Minister - he offered 'blood, toil, tears, and sweat.' By early June the 'miracle' of Dunkirk was offering some encouragement, but this was offset by the evacuation of British troops from Norway with several thousand casualties. July to August saw the Battle of Britain with the Blitz on London, and throughout this period the loss of Allied shipping caused continuing apprehension. By the end of the year Britain stood alone against Germany and Italy, with Russia uncommitted in the wings.

It was against this background that Leslie John Comrie made the decision to ship a large quantity of books and serial and periodical publications to the Carter Observatory in Wellington.

Comrie was an expatriate New Zealander who had been Superintendent of the British Nautical Almanac Office, had established Scientific Computing Services Ltd in London and was an acknowledged leader in numerical computation before the advent of electronic computers. He was also regarded as the leading table maker and table editor of his day. ${ }^{1}$

\section{The principal gift}

Although no direct evidence of his rationale has so far been found in the correspondence in Carter archives, anecdotal evidence from George A Eiby is recorded in Tee $(1981,85)$.

Comrie had built up the world's finest library on computation..... He considered very seriously the question of whether Europe could survive as a civilized region.

Accordingly, in 1941 he shipped out to New Zealand many thousands of early scientific books so that, should Europe perish, then some of its finest achievements might yet survive for later generations.

Eiby was a physicist at the Seismological Observatory and an Honorary Associate at the Carter Observatory at the time Comrie toured New Zealand

\footnotetext{
${ }^{1}$ See Rollo 2001, 21-31. See also Croarken 1990 and 2000, 114.
} 
in 1948. The two observatories were within 100 metres of each other on their hilltop site at the southern edge of the Botanic Gardens. Comrie's visit to Wellington may have provided the opportunity for Eiby to learn at first hand Comrie's reasons for sending the publications out of Britain. Perhaps he was influenced by the Greenwich Observatory sending long series of their Greenwich Observations to New Zealand (now housed at Carter). Or he may have been influenced (Perkins pers. comm.) as

there is an echo of similar action taken at this period. I am thinking of the time-service being available from Edinburgh as well as Abinger because of the danger of enemy action during the war destroying this all-important service at the principal site.

Additional anecdotal evidence about the transfer of the collection to New Zealand is offered by John Harper ${ }^{2}$ who recalls (Harper, pers. comm.)

When I was on the Carter Observatory Board some 25 years ago we were told that one reason Comrie had sent it was that if all British libraries had been destroyed in the Second World War positional astronomy could have been reconstructed from it.

Both explanations clearly display a concern for the preservation of mathematical and astronomical techniques and historical achievements. One can only speculate as to Comrie's assessment of the risk of the loss of the books by enemy action at sea.

A search of Carter archives has not revealed any letters to or from Comrie about his major gift. It was made when the Observatory was virtually in recess while its principal staff were engaged in military service. However, the minutes of the Observatory Board of 7 March 1941 record, under a heading 'Books being sent by Dr. Comrie':

The Director [M. Geddes] read correspondence received from Dr. L.J. Comrie, London, in which he was informed that Dr. Comrie was sending to the Carter Observatory a large number of books. The Director was instructed to write to Dr. Comrie and express the Board's gratitude for his action.

There is a record in a financial report to the Board of a payment during March 1941 for insurance on the books (valued at £300) received from

${ }^{2}$ Emeritus Professor of Mathematics, Victoria University of Wellington, and a member of the Carter Observatory Board for eight years. The initial period of his service on the Board coincided with the final years of Ivan. L. Thomsen's service as Carter's Director (1945-1969). 
Comrie. This valuation was almost the equivalent of the then annual salary of one of the Observatory's professional staff - a valuable gift indeed.

The Annual Report of the Director of the Carter Observatory for the year ending 31 March 1941 records, under the sub-heading library:

The main library has been housed as previously in the Dominion Observatory....

By far the most substantial addition to the library was the gift by Dr. L.J. Comrie, of London, of 14 cases of books. These have arrived in good condition, but, owing to shortage of space in the present building, have not yet been unpacked.

[The Dominion Observatory was adjacent to the Carter Observatory and incorporated the Seismological Observatory for a period. The building is currently unoccupied and managed by the Department of Conservation.]

In the succeeding year, the Report of the Representatives of the Royal Society of New Zealand on the Carter Observatory Board, notes that:

The astronomical library of the Dominion Laboratory, mentioned in the last report, was transferred into the library room of the new building. This was augmented by a valuable gift from Dr. L.J. Comrie, London, of fourteen cases of books consisting for the most part of the private libraries of the late Dr. A.C.D. Crommelin and Mr. H.P. Holles, both formerly of the Greenwich Observatory. The present library is therefore very well stocked and will prove to be a valuable source of astronomical information.

These reports and anecdotes disclose two explanations for the gift; a reasonably close inference of the timing of its despatch and receipt in New Zealand; and its valuation, both in monetary and astronomical terms.

At some point after their arrival in New Zealand all the items were endorsed with a green ink rubber stamp stating 'Carter Observatory / Present by / Dr L J Comrie / 1941'. Some of the items carry Comrie's handwritten endorsement 'Presented to Carter Observatory / L. J. Comrie / 1940 Oct 28'. ${ }^{3}$

A catalogue of the 1940 books and journals was prepared (Carter file 9/25/1) and may well have been the catalyst for an item in The Dominion of 18 June 1941 publicly recording the gift. This item records 'Some of the books date back to 1708' and that 'a week after the books were shipped a bomb went through the building in which they had been kept in London.... Their voyage to New Zealand illustrates in a small way one of the effects of the war

3 This year, month, day date format was and still is commonly and widely used by astronomers. The ISO format is 1940-10-28. 
in the dispersal of libraries from the old world to the new.' No record of the source of this comment has been found.

The catalogue is effectively divided into two sections: serial and periodical journals segregated by country of origin, comprising well in excess of 2000 items; and some 350 books classified in groups such as longitude publications, tidal research, geodesy, variable stars, star catalogues, double stars, astro-graphic catalogues, general astronomical literature, general physics, mathematics, general literature - mainly scientific and philosophical, but some biographical items.

Pride of place in the journal section is given to the Nautical Almanac. The catalogue records a broken series starting 1770-1772, 1787, 1792 and ending in 1939. All told there are 85 annual volumes, inclusive of 24 duplicates. $^{4}$

The other journal items clearly show their origins as being the private and professional interests of two astronomers. They include a long run of unbound parts of the monthly notices of the Royal Astronomical Society covering the period 1900 to 1939 , with many duplicates of some issues. The Almanac issues for this period almost certainly came from this source. Similarly, there are many duplicates of The Observatory covering the period 1904 to 1939.

Of the total journal material, about 40 per cent are UK titles, including regional astronomical societies and university observatory publications; 25 percent are Continental sources and titles; 18 per cent North American items, and the remainder include a substantial component from South Africa, as well as South American, Japanese, and Australian titles.

Of the books, 25 titles were donated, with other rare books from the Carter Observatory, to the Alexander Turnbull Library, where they are held in the Special Printed Collections. Six titles were published in the 18th century and the one that excites mathematicians' interest is a 1737 edition of Thomas Simpson's $A$ new treatise of fluxions wherein the direct and inverse method are demonstrated...(London: Gardner, 1737), - one of only sixteen copies recorded in the English Short Title Catalogue. The 1708 volume mentioned in the press item does not carry the Comrie presentation stamp. It is Jacques Ozanam's Recreations mathematical and physical... by M. Ozanam, Done into English and illustrated with very many cuts (London: R. Borswick, 1708).

\footnotetext{
${ }^{4}$ The Almanac was first issued in 1767 by the Commissioners of Longitude, subsequently by the Lord Commissioners of the Admiralty from 1832-1959, and thereafter, and currently, jointly by H.M. Nautical Almanac Office and the Nautical Almanac Office, US Naval Observatory. Comrie joined the Nautical Almanac Office in 1925 and served as Superintendent from 1930 to 1936.
} 
However, two sets of an 1803 edition of Ozanam at Turnbull both carry the presentation stamp'. ${ }^{5}$

The remainder of the books are not segregated into a Comrie Collection as such, but are scattered through the working library of the Carter director's office and the formal Carter library. No entries have been found in the disused card catalogue for the Observatory, suggesting that the Comrie material, other than journals, was stored in the Director's office. A random selection of items from both locations frequently turns up volumes with the green Comrie presentation stamp.

\section{Subsequent gifts}

A Carter file covering the period 1945-1951 deals exclusively with subsequent Comrie book gifts. Not all copies of the then Director's ${ }^{6}$ outgoing letters are included, but Comrie's replies identify some of the issues raised with him about the disposal of items sent to New Zealand.

What is clear from the correspondence is Comrie's method of expanding his own library resources and his attitude to dispersal of the material sent to New Zealand.

Comrie bought up the libraries of deceased astronomers, which presumably were incorporated into the Scientific Computing Service library. Over time he amassed material outside his own interests or needs, and then gave some of this material to Carter, or nominated individuals in New Zealand to whom specific items should be sent or offered.

Comrie was in North America to preside at a conference held at the Massachusetts Institute of Technology ... by a committee of the National Research Council of the USA when his secretary responded (postmarked 1945 November 28) to a Thomsen enquiry. She reported she was endeavouring while Comrie was away to arrange for another consignment of astronomical books to be sent to the Observatory. 'They are mainly from the library of the late Frank Robbins ....'

The letter goes on to record:

The New Zealand Govt. department over here that sometimes helps us to send you books has today promised to undertake to pack and despatch this batch - but they can't do it for a week or so because they're overwhelmed with arranging troop transports

\footnotetext{
${ }^{5}$ I am indebted to Robert Petre, Curator, Special Printed Collections, Alexander Turnbull Library for making a special search for the 1708 item, and for identifying the 1803 edition as part of the Comrie gift.

${ }^{6}$ Ivan L. Thomsen succeeded Murray Geddes, the first Director, who died in Scotland in 1944 while on service with the RNZVR.
} 
at present. As you know, Dr. Comrie also despatched (via the same people) another lot of books and periodicals to the Observatory a few months ago - perhaps you may even have received them by now.

Comrie clearly had ideas or suggestions for the use of these publications, as the same letter notes 'Dr. Comrie mentioned the distribution of the books in a letter dated July 27 addressed to the Acting Secretary (Mr Coppin) of the Carter Observatory.'

As the Comrie gifts were primarily the private libraries of professional astronomers, there was some duplication of titles, and the Board 'authorised the Director to dispose of these to best advantage.'

On 1946 January 18 Comrie was writing:

As far as the library is concerned, I quite approve of the idea of putting the technical stuff in the Carter Observatory and the popular stuff in the N.Z.A.S. [New Zealand Astronomical Society] library.... What I really want you and Berry ${ }^{7}$ to do is place the duplicate stuff where it will be appreciated, and especially to give it to people like Berry and Jones personally.

Comrie's letter of 1946 February 18 mentions that a further collection was being assembled and

only this morning I put on one side the Nautical Almanac for 1934 and 1935, of which spare copies have been handed to me. Some member of the N.Z.A.S. who does not get the Nautical Almanacs regularly may like one of these for the sake of the explanation and Fetheringham's article on the calendar, which is no longer printed in full.

Amongst these duplicates was a copy of the Penny Cyclopedia Vols.1-27, the same publication Comrie acknowledged as one of the sources of his guidance on the typography of tables (Rollo (2001) 24, 30).

This file shows that Thomsen, in distributing duplicates or single titles, made his selections to support the work of institutions and their staff and the known interests amateur astronomers. Items were distributed as far afield as Kaitaia in the north and Dunedin in the south.

${ }^{7}$ D. C. Berry (then Dunedin and now Auckland) and A. F. Jones (then Timaru and now Stoke, Nelson) were amateur astronomers with numerous contacts with other astronomers and institutions. Both were mentioned in Comrie's report to a British Astronomical Association meeting [1948 November 2] of his visit to New Zealand and Australia. In 2004 Albert Jones' contribution to astronomy was recognised, in addition to his recognition by learned societies, by an honorary D Sc (VUW), based on a life's work largely carried out with a telescope which Comrie helped to provide. 
Another gift in 1948 comprised 26 books from the estate of B F Bawtree, and were shared between Carter and the two South island astronomers.

On another occasion (1948 September 22) Comrie offered 'We have a heap of old N.A.'s about - are there any that you would like? There are one or two old specimens - about 1838!' Thomsen responded a month later (1948 October 28) with a list of Almanacs missing from the Carter library. In the same letter, he asked Comrie

If you want to get rid of any [Almanacs] from 1931 onwards, or Abridged Nautical Almanacs of recent years, I can take all you wish for passing to the Naval Reserve which is once more getting under-way. The C.O. thought they would be useful for training purposes, when I rang him the other day. I think they would do more good there than languishing [on] the shelves of some Society - unused, unvalued, over the years.

A Comrie assistant replied (1948 November 26) saying that they were sending sixteen Abridged Almanacs and 'hope you find them useful.'

Clearly Comrie's gifts, and the policy for their distribution, represent an extremely generous and thoughtful support of professional and amateur astronomical activities in New Zealand, more particularly of the Carter Observatory when it was a fledgling institution. Other research institutions, universities, regional astronomical societies, the Naval Reserve and numerous individuals also received support and encouragement from these gifts. At least one Comrie gift book has reached the secondhand market.

One view of Comrie's gifts is [New Zealand was] 'very lucky that Comrie had foresight and opportunity as well as brains'.

The gifts also re-enforce, in a slightly different context, James Belich's assessment (Belich, 2001, 342) of the role of expatriate New Zealanders' contribution to our culture - 'Yet New Zealand had good access to the cultural output its expatriates helped create - brains out, books back.'

\section{Acknowledgements:}

I wish to acknowledge both the goodwill and the assistance of the Board and management of the Carter Observatory for giving me access to their archives, particularly John Whiffin and Kay Leather; and Brian Carter, Senior Astronomer, for contacts that greatly expanded my access to Comrie material in Britain.

I am grateful to Mary Croarken, Harry Orsman, Garry Tee, and John Whiffin for comments and suggestions about points in this paper.

\section{Works Cited}

Belich, James. Paradise Reforged A History of the New Zealanders. [Allen Lane The Penguin Press] Penguin Books (NZ) Ltd, 2001. 
Croarken, Mary. Early Scientific Computing in Britain. Oxford University Press, 1990.

Croarken, Mary. L J Comrie: A Forgotten Figure in the History of Numerical Computing Mathematics Today August, 2000.

Harper, John. personal communication: email message 20 November 2001.

Perkins, Adam J. Royal Greenwich Observatory Archivist personal communication: email message 17 December 2001.

Rollo, Lindsay. The typography of tables. A note on L.J. Comrie. Kotare: New Zealand Notes and Queries, Vol 4 No. 1, June 2001.

Tee, G. J. Two New Zealand Mathematicians. Proceedings of the First Australian Conference on the History of Mathematics. Monash University, Melbourne, 1981. 